\begin{tabular}{|c|c|c|}
\hline $\begin{array}{l}\text { EXCELLENT } \\
\text { PUBLISHERS }\end{array}$ & $\begin{array}{l}\text { International Journal of Current Research } \\
\text { and Academic Review } \\
\text { ISSN: 2347-3215 (Online) } \\
\text { Journal homepage: holtp://www.ijcrar.com } 5 \text { (May-2017) }\end{array}$ & 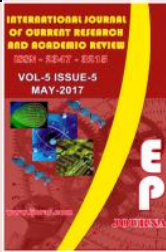 \\
\hline
\end{tabular}

doi: $\underline{\text { https://doi.org/10.20546/ijcrar.2017.505.012 }}$

\title{
Entrepreneurship Education and its Promotion
}

\author{
Paras Jain*
}

Director, Silicobyte KDC Katni Degree College, Dikshabhumi Campus, Adharkap, Katni (M.P), India

*Corresponding author:

\begin{abstract}
Education has always been an honored place in Indian society. Entrepreneurship should involve in education for economic, social and industrial development of nation. We need efforts to enhance entrepreneurship education at all stages. Education of entrepreneurship is necessary with all general and professional courses. The education system must produce young entrepreneurs with ethics, character, and capabilities and committed to society and nation. We need to promote entrepreneurial education through national program by innovation, creating entrepreneurs and strengthening national economy. Present study focused on student's interest towards study of entrepreneurship education.
\end{abstract}

\section{Article Info}

Accepted: 30 April 2017

Available Online: 20 May 2017

\section{Keywords}

Entrepreneurship , Promotion , Education.

\section{Introduction}

To understand entrepreneurship, a suitable program should be developed in the curriculum. This may be designed starting with the photographs of entrepreneurs and their innovation followed by essay, stories, projects etc. It could be ensured that each child enrolled in school is aware with understanding of entrepreneurship. Children could be initiated to think of doing creative and move towards innovation. In higher classes of schools the curriculum could be restructured with the inclusion of entrepreneurship chapter in each class text book with respect to their correlation.

Entrepreneurship could work as a spark to develop entrepreneurs and bring the change and transformation. School could initiate for tie ups with industries for student's visit to create entrepreneurship environment and practical experience. Technical and vocational education should link with entrepreneurship education. Correlation of school and entrepreneurship could be an integral part of education and technical based entrepreneurship could be conducted by teachers. The students at the graduation level could be provided with entrepreneurship. It could be introduced as a subject or part of subject. Special attention could be given to the Post Graduation courses. The college and university could specially treat the students with care and efforts to energize entrepreneurship which could enable the success. Open discussion regarding entrepreneurship should be introduced to develop entrepreneurial environment. Practical training could form an integral part of technical education. Technical education and practical training could be related closely with banks and Industry to develop, encourage and provide continuous nourishment to the young entrepreneurs.

Engineering colleges and management colleges could tie up teachers, labs and other necessary elements as per their need for mutual development and support to students for the enhancement of entrepreneurship environment. Institute could be taken to promote the tie 
up between banks and Universities to facilitate and activate entrepreneurship environment. Entrepreneurship University could be established at national level with the affiliation of colleges.

There could be a continuous review and research to maintain a proper balance between output of entrepreneurship and job seekers. Stress could be placed on the need to support entrepreneurship research. Part time entrepreneurship correspondence course could be developed. These courses may promote entrepreneurship education and opportunities to the unemployed. For the cultivation of entrepreneurship excellence, talent of the students in diverse fields could be identified as early an age as possible. Entrepreneurship could be promoted by media.

\section{Objective of Study}

To find student's interest towards entrepreneurship education among school and college students

To find student's interest gender wise towards entrepreneurship education among school and college students

To find student's interest locality wise towards entrepreneurship education among school and college students

\section{Hypothesis}

There is no significant difference gender wise for student's interest towards entrepreneurship education.

There is no significant difference locality wise for student's interest towards entrepreneurship education.

\section{Methodology}

Descriptive survey method was applied. A survey was conducted with students of different courses. They were tested using a self prepared questionnaire. 360 students were taken for experiment and classified according to course/class. 60 students of class 6-8, 60 students of class $9-12,60$ students of general graduation course, 60 students of general post graduation course, 60 students of engineering course, 60 students of medical course were selected randomly for study. In each class $50 \%$ boys and $50 \%$ girls and $50 \%$ rural and 50\% urban were included. Data was tabulated gender wise and locality wise. Student's interest was converted into percentage and analyzed.

\section{Finding \& Analysis}

Gender wise comparison shows that $52 \%$ boy and $43 \%$ girl students of class 6-8 showed interest towards entrepreneurship education while from class 9-12, 56\% boys and $45 \%$ girls expressed their interest. General graduation course students take higher interest i.e., $63 \%$ boys and $57 \%$ girls exhibited interest. Interest of PG course students is less i.e., $44 \%$ boys and $36 \%$ girls took interest. Engineering students showed highest interest, $66 \%$ boys and 58\% girls found interested.

Table.1 Status of Gender wise Student's Interest towards Entrepreneurship Education

\begin{tabular}{|l|c|c|}
\hline \multirow{2}{*}{ Course / Class } & \multicolumn{2}{|c|}{ No. of Interested Students (\%) } \\
\cline { 2 - 3 } & Boys & Girls \\
\hline Class 6-8 & 52 & 43 \\
\hline Class 9-12 & 56 & 45 \\
\hline $\begin{array}{l}\text { General } \\
\text { Graduation Course }\end{array}$ & 63 & 57 \\
\hline $\begin{array}{l}\text { General Post } \\
\text { Graduation Course }\end{array}$ & 44 & 36 \\
\hline Engineering & 66 & 58 \\
\hline Medical & 8 & 4 \\
\hline
\end{tabular}


Table.2 Status of Locality wise Student's Interest towards Entrepreneurship Education

\begin{tabular}{|l|c|c|}
\hline \multirow{2}{*}{ Course / Class } & $\begin{array}{l}\text { No. of Interested } \\
\text { Students (\%) }\end{array}$ & \\
\cline { 2 - 3 } & Rural & Urban \\
\hline Class 6-8 & 44 & 53 \\
\hline Class 9-12 & 54 & 60 \\
\hline $\begin{array}{l}\text { General } \\
\text { Graduation Course }\end{array}$ & 53 & 66 \\
\hline $\begin{array}{l}\text { General Post } \\
\text { Graduation Course }\end{array}$ & 39 & 42 \\
\hline Engineering & 56 & 69 \\
\hline Medical & 5 & 7 \\
\hline
\end{tabular}

Chart.1 Status of Gender wise Student's Interest towards Entrepreneurship Education

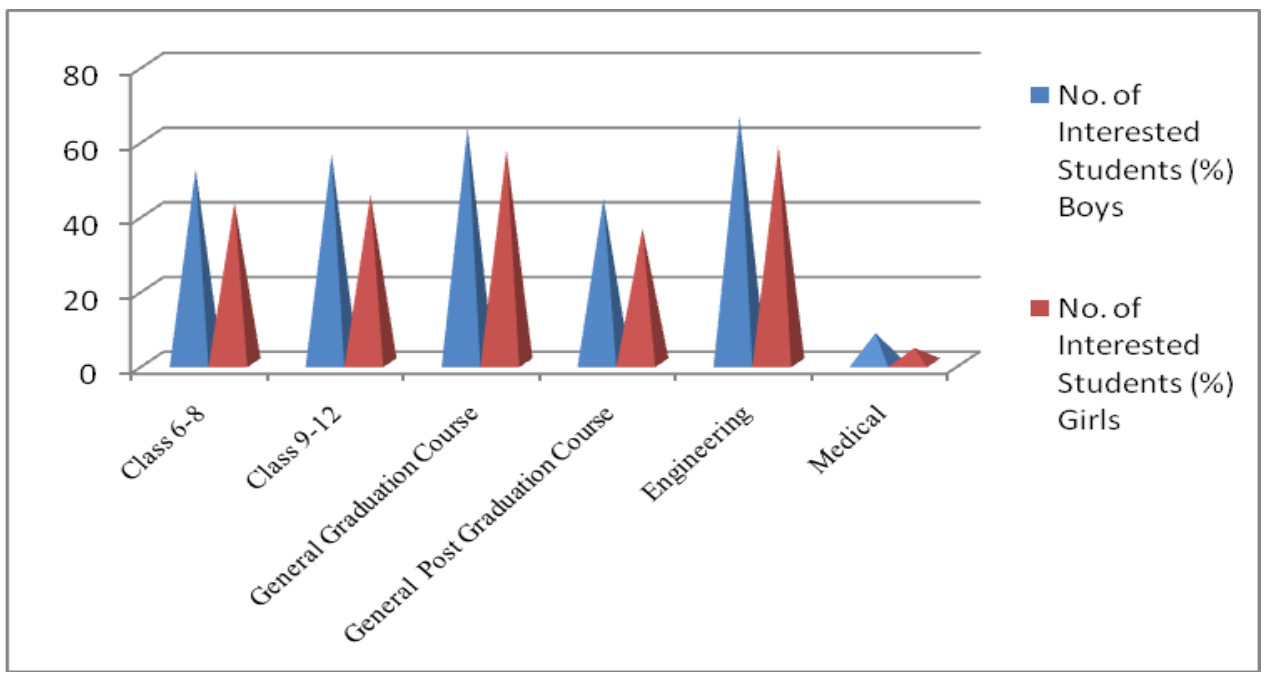

Chart.2 Status of Locality wise Student's Interest towards Entrepreneurship Education

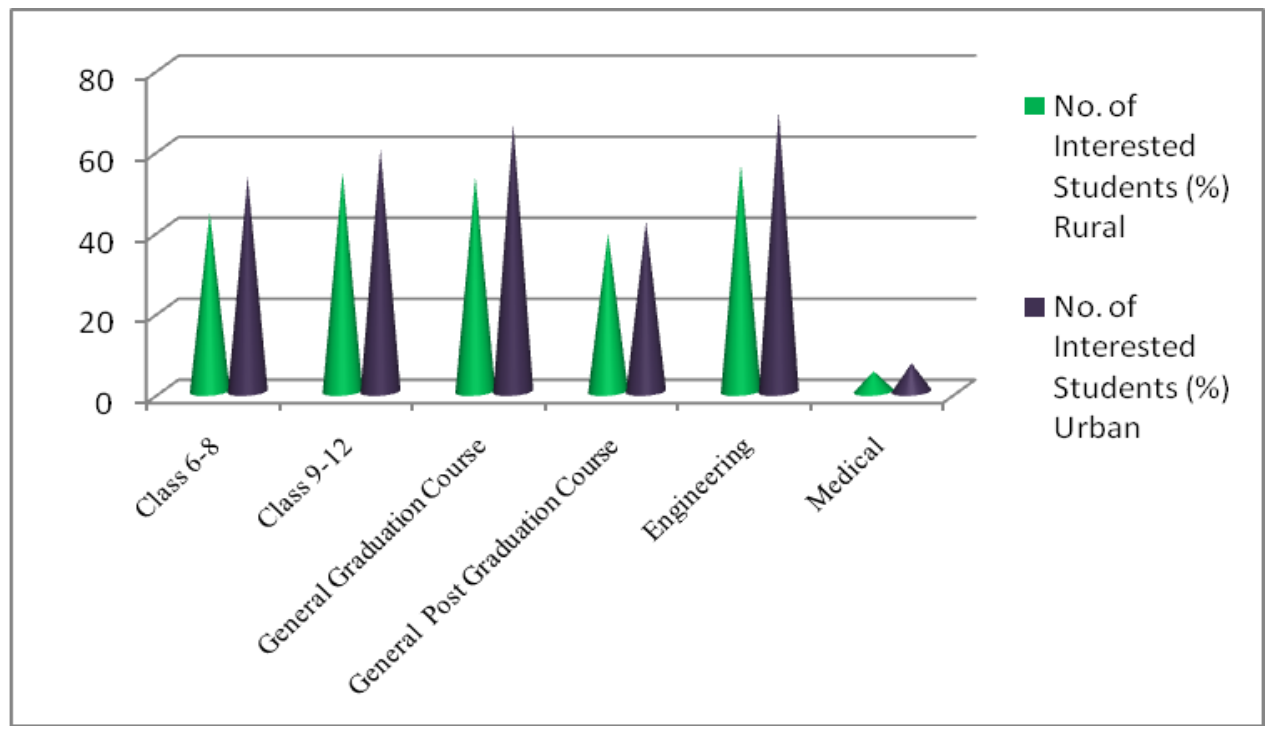


Medical course students expressed minimum interest, $8 \%$ boys and $4 \%$ girls expressed their interest. Thus boys took more interest than girls; hypothesis 1 there is no significant difference gender wise for student's interest towards entrepreneurship education is rejected.

Locality wise data indicates that in the category of Class 6-8, 44\% rural and 53\% urban students showed interest in entrepreneurship education while in the category of 9$12,54 \%$ rural and $60 \%$ urban took interest. Among students of general graduation course 53\% rural and 66\% urban, from general PG degree course 39\% rural and $42 \%$ urban exhibited interest. Urban engineer's interest remarked as highest interest i.e., 69\% while rural engineer's interest was $56 \%$. Medical student $\%$ is minimum i.e., $5 \%$ for rural and $7 \%$ for urban. Urban student's interest towards entrepreneurship education is greater rather than rural students; hypothesis 2 there is no significant difference locality wise for student's interest towards entrepreneurship education is rejected.

\section{Conclusion}

In present study school level students expressed their interest to study entrepreneurship. Boy student's \% is higher who took interest in entrepreneurship study rather than girl students. Engineering student's interest \% is higher in comparison of other courses and medical student's \% is lower. Remarkable fact is derived that class 6-12 students have showed interest in entrepreneurship education.

It is necessary for India to attain its deserving place in the world by promoting entrepreneurship education in the country. The govt. should promote entrepreneurship development programs. Educational institute may celebrate entrepreneurship day, organizing seminars, workshops and motivational lectures. School, Colleges may invite and discuss new ideas, market trends, information related to special efforts, exhibitions, motivating schemes. Women entrepreneurs, rural and urban entrepreneurs should be promoted by taking initiatives for talk shows, media coverage and publication.

\section{References}

1. Singh, H.S., Entrepreneurship education and its promotion: An overview, Psycho Lingua, 43 (2), 2013.

2. Aggarwal, J.C., Teacher Education Theory and Practice, Doaba House, Delhi, 1998

\section{How to cite this article:}

Paras Jain. 2017. Entrepreneurship Education and its Promotion. Int.J.Curr.Res.Aca.Rev. 5(5), 93-96.

doi: https://doi.org/10.20546/ijcrar.2017.505.012 